\title{
Introduction to the Kowalevsky medal issue
}

\author{
By Guest Editor Alexander Ereskovsky
}

Aix-Marseille University, CNRS, Mediterranean Institute of Biodiversity and Ecology,13007 Marseille, France

The year 2011 marks the 110th anniversary of the death of one of the most significant 19th-century biologists working at the intersection of evolution and embryology, Alexander Onufrievich Kowalevsky (Raff and Love 2004). The year 2011 also marks the first jubilee, 10 years of the reestablishment of the Alexander Kowalevsky Medal award of the Saint-Petersburg Society of Naturalists ( $\mathrm{SPbSN}$ ) for extraordinary achievements in evolutionary developmental biology and comparative zoology (http://www.spboe.ru/en/ award/index.html).

The Kowalevsky medal has a long story. The SPbSN, which was founded in 1868 at St. Petersburg University, established an international award in the name of Alexander Kowalevsky, a professor of the University, in the 1910s. The award consisted of a medal and a monetary prize of 250 gold rubles. The medallist of the Russian Imperial Mint, Piotr G. Stadnitsky, created the plaque of the medal. The front face portrayed A. Kowalevsky after the bas-relief made presumably by sculptor and painter Olga N. Metschnikoff (the wife of Elias Metschnikoff) (Tokin 1958). The reverse side displayed the sea bed with various invertebrates studied by Kowalevsky. The medal was intended to be awarded for research in comparative anatomy and embryology of animals. Manufacturing of medals and creation of the award fund were delayed and the award was never given. The First World War broke out in 1914, then the February and October Russian revolutions of 1917 took place, the civil war that lasted for many years that led to the devastation of the country. All the disasters endured by Russia made the decision of $\mathrm{SPbSN}$ on the international award untimely, and the award sank into oblivion.

The Kowalevsky medal re-emerged in 2000. Thanks to activity of the President of SPbSN, Professor Archil K. Dondua, the medal was rediscovered in the numismatic collection of the State Hermitage in St. Petersburg. It turned out that the medal was manufactured at the St. Petersburg Mint and that the Mint Museum still had the molds for casting the medal. Unfortunately, the upper edge of the mold with the signature of A. O. Kowalevsky was damaged and had to be removed. Nevertheless, the medal was restored by efforts of the St. Petersburg Mint medallists.

In March 2001, the Academic Council of the SPbSN reinstated the international award of the Society in commemoration of the 100th anniversary of A. O. Kowalevsky's death.
The award would include a diploma and bronze medal in its original form. Since 2001, the medal has been annually awarded for distinguished achievements in comparative zoology and comparative evolutionary embryology to researchers who made significant contribution to modern ideas on the phylogeny of animals, and evolutionary developmental biology. The Medal Award Regulations specify that the medal in commemoration of Professor A. O. Kowalevsky "should be awarded for applying modern approaches in embryology and evolution studies" (Dondua and Alexandrov 2002; Mikhailov and Gilbert 2002).

In the year of the reinstatement of the medal (2001), the award was given to several distinguished researchers of the 20th century whose works made great contribution to comparative evolutionary morphology and embryology. The award procedure was based on the recommendation letters obtained from the nominators (over 25 persons) from different countries. To hold the nomination, an international Awarding Committee was elected that consisted of wellknown international scientists. The final selection for the award was based on a full list of names ranked according the number of nominations.

This special issue is dedicated to two foregoing jubilees. The authors of this issue are the winners of the Alexander Kowalevsky Medal, and the members of the Awarding Committee. The editors of "Evolution \& Development" have kindly given an opportunity to realize this project. The issue begins with two papers devoted to the biography of $\mathrm{A}$. Kowalevsky (Fokin) and the historical analysis to the contribution of Russian embryology in formation of modern evolutionary developmental biology (Mikhailov).

The themes of the articles of the second part concern the actual questions of modern evolutionary embryology/developmental biology. S. Gilbert analyses the ability of organisms to respond to environmental cues by producing different phenotypes and their evolutionary sequences. The relationships between concept/category of parallelism, homology, and convergence based on developmental/genetic mechanisms are discussed by B. Hall. W. Gehring discusses the establishment of the body plan, the evolution of the Hox genes, and evolution of eyes from an evolutionary prototype. G. Freeman's review deals with the mechanisms that operate during anticipatory development of lecithotrophic larvae. Two last papers concern two central problems in chordate 


\section{EVOLUTION \& DEVELOPMENT Vol. 14, No. 1, January-February 2012}

evo-devo: the molecular and developmental understanding of the evolutionary scenario of jaw acquisition (Kuratani), and the molecular mechanisms of notochord origin and evolution with a special emphasis on a member of the T-box gene family, Brachyury (Sato with coauthors).

\section{LIST OF KOWALEVSKY MEDALLISTS}

In 2001, the medal was awarded to Donald Thomas Anderson (University of Sydney, Australia), Gary Freeman (Texas University in Austin, USA), Brian Hall (Dalhousie University, Canada), Olga M. Ivanova-Kazas (St. Petersburg State University, Russia), Claus Nielsen (Copenhagen University, Denmark), Rudolf Raff (Indiana University in Bloomington, USA), Rupert Riedl (Vienna University, Austria), and Klaus Sander (Freiburg University, Germany).

Since 2002, only one medal has been awarded annually. In 2002, the medal was awarded to Eric Davidson, Professor of California Institute of Technology (USA); in 2003 to Walter Gehring, Professor of University of Basel (Switzerland); in 2004 to Scott Gilbert, Professor of Swarthmore College (USA), Honorary Member of SPbSN; in 2005 to Nori Satoh, Professor of Department of Zoology, Kyoto University (Japan); in 2006 to Peter Holland, Professor of
Oxford University (UK); in 2007 to Michael Akam, Professor of Cambridge University and Director of university's Museum of Zoology (UK); in 2008 to Sean B. Carroll, Professor of Molecular Biology and Genetics of Howard Hughes Medical Institute, University of Wisconsin (USA); in 2009 to Mark Q. Martindale, Director of the Kewalo Marine Laboratory and Professor in the Pacific Biosciences Research Center at the University of Hawai'i at Manoa (USA); in 2010 to Professor Shigeru Kuratani from the Center for Developmental Biology, Kobe (Japan); and in 2011 to Professor Detlev Arendt, European Molecular Biology Laboratory, Heidelberg (Germany).

\section{REFERENCES}

Dondua, A. K., and Aleksandrov, D. A. 2002. International Award of the St. Petersburg Society of Naturalists - Alexander Kowalevsky Medal. Russ. J. Dev. Biol. 33: 324-325.

Mikhailov, A. T., and Gilbert, S. 2002. From development to evolution: the re-establishment of the "Alexander Kowalevsky Medal". Int. J. Dev. Biol. 46: 693-698.

Raff, R. A., and Love, A. C. 2004. Kowalevsky, comparative evolutionary embryology, and the intellectual lineage of Evo-Devo. $J$ Exp. Zool. (Mol. Dev. Evol.) 302B: 19-34.

Tokin, B. P. 1958. About new documents, concerning the life and scientific work of A.O. Kowalevsky. Vestnik Leningrad State University 9: $57-65$. 